
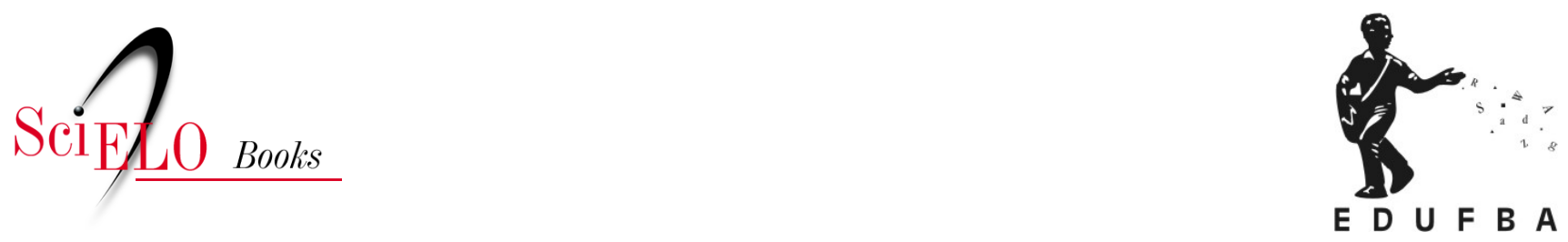

\title{
Reflexões \\ Querem mutilar o Marco Civil da Internet
}

\author{
Nelson De Luca Pretto
}

PRETTO, N.D.L. Querem mutilar o Marco Civil da Internet. In: Educações, culturas e hackers: escritos e reflexões [online]. Salvador: EDUFBA, 2017, pp. 102-103. ISBN: 978-85-232-2019-8.

https://doi.org/10.7476/9788523220198.0013.

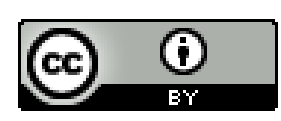

All the contents of this work, except where otherwise noted, is licensed under a Creative Commons Attribution $\underline{4.0 \text { International license. }}$

Todo o conteúdo deste trabalho, exceto quando houver ressalva, é publicado sob a licença Creative Commons Atribição 4.0. 
qualidade e acessível a todos. O que temos 20 anos depois? Absolutamente nada em termos de um plano de banda larga para o Estado. Com a palavra os senhores candidatos.

Publicado no jornal Correio*, Salvador, em 2 de abril de 2014.

\section{Querem mutilar o Marco Civil da Internet}

Ao longo dos últimos anos, entidades da sociedade civil estiveram reunidas em uma forte articulação nacional no movimento Marco Civil Já. Foram anos de muita discussão para que o país pudesse ter uma Constituição para a internet que garantisse direitos e liberdades para o cidadão, no uso da rede.

Depois de muita luta, o Marco Civil da Internet (MCI) foi aprovado (Lei 12.965/2014), trazendo garantias a direitos fundamentais para os usuários da rede, como a privacidade e a liberdade de expressão, em consonância com orientações internacionalmente aceitas de governança da internet. Nossa Lei foi saudada em todo o mundo. Estávamos garantindo que a internet continuasse como ela de fato nasceu: um espaço da liberdade e não um espaço aprisionado pelo modelo de negócios das operadoras de telecomunicações.

Mas as tentativas de mutilar essa Lei não pararam desde a sua aprovação.

Hoje teremos mais um capítulo desta novela, quando a Comissão de Constituição e Justiça da Câmara dos Deputados votará o PL 215/15, do Deputado Hildo Rocha (PMDB/MA) e seus apensos: PL 1547/15 (De- 
putado Expedito Netto, SD/RO) e PL 1.589/2015 (Deputada Soraya Santos, $\mathrm{PMDB} / \mathrm{RJ})$.

O que se quer com tudo isso é criminalizar todas as ações na internet.

O movimento Marco Civil Já reagiu rápido e lançou uma carta pública denunciando esse jogo rasteiro no Congresso. $\mathrm{Na}$ carta, fica claro que, com as modificações propostas para o Código Penal, associadas à alteração proposta na Lei do MCI, o que se busca é "permitir que dados dos usuários sejam fornecidos a autoridades públicas independentemente de ordem judicial, assim como a obrigatoriedade de retirada de conteúdos postados na internet, nos casos de mera alegação de crimes contra a honra - calúnia, injúria e difamação -, impondo penalidades de restrição física e econômicas ao provedor de internet, comprometendo o princípio da inimputabilidade da rede. Entre os dados dos usuários que podem ser obtidos sem ordem judicial estão os conteúdos de comunicações na Internet: e-mails, mensagens e conversas no Skype e Whatsapp, por exemplo."

Associo-me de forma contunde a todos que repudiam essas iniciativas parlamentares que atentam contra a privacidade e a liberdade de expressão. Não podemos aceitar que essa onda conservadora de vigilância, ganhando força a cada dia no Congresso Nacional, destrua nossas mais recentes conquistas.

A carta enviada aos parlamentares foi direta: "O PL 215/15 coloca em risco o necessário equilíbrio entre a proteção do direito à privacidade e a persecução criminal, bem como a própria democracia ao permitir tais abusos." É bom lembrar que "Tais proposições já foram rejeitadas durante a tramitação do MCI. Aliás, vale destacar que os dispositivos hoje presentes no Marco Civil foram resultado de um amplo debate social e de uma intensa negociação política, o que torna esta uma das leis mais democráticas já votadas na recente história do Congresso Nacional."

Não deixem que mutilem ainda mais o nosso Marco Civil da Internet. 